\title{
A survey of fishes associated with Hawaiian deep-water Halimeda kanaloana (Bryopsidales: Halimedaceae) and Avrainvillea sp. (Bryopsidales: Udoteaceae) meadows
}

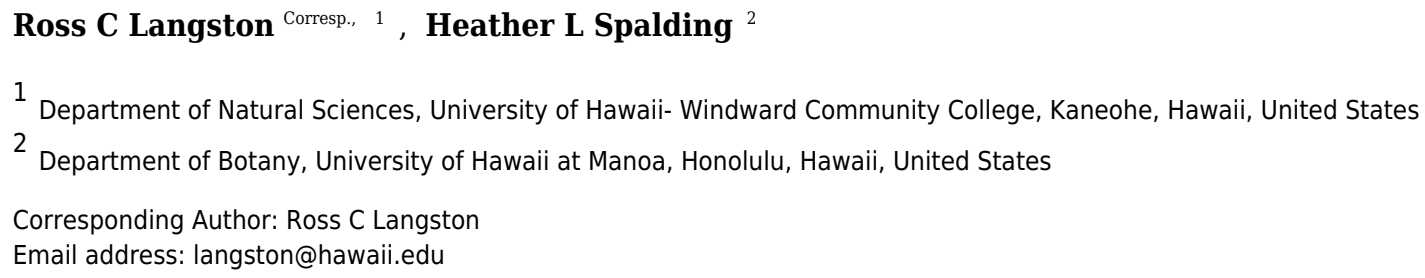

The invasive macroalgal species Avrainvillea sp. and native species Halimeda kanaloana form expansive meadows that extend to depths of $80 \mathrm{~m}$ or more in the waters off of O'ahu and Maui, respectively. Despite their wide depth distribution, comparatively little is known about the biota associated with these macroalgal species. Our primary goals were to provide baseline information on the fish fauna associated with these deep-water macroalgal meadows and to compare the abundance and diversity of fishes between the meadow interior and sandy perimeters. Because both species form structurally complex three-dimensional canopies, we hypothesized that they would support a greater abundance and diversity of fishes when compared to surrounding sandy areas. We surveyed the fish fauna associated with these meadows using visual surveys and collections made with clove-oil anesthetic. Using these techniques, we recorded a total of 49 species from 25 families for $H$. kanaloana meadows and surrounding sandy areas, and 28 species from 19 families for Avrainvillea sp. habitats. Percent endemism was $28.6 \%$ and $10.7 \%$, respectively. Wrasses (Family Labridae) were the most speciose taxon in both habitats (11 and six species, respectively), followed by gobies for $\mathrm{H}$. kanaloana (six species). The wrasse Oxycheilinus bimaculatus and cardinalfish Apogonichthys perdix were the most frequently-occurring species within the $H$. kanaloana and Avrainvillea canopies, respectively. Obligate herbivores and food-fish species were rare in both habitats. Surprisingly, the density and abundance of small epibenthic fishes were greater in open sand than in the meadow canopy. In addition, species richness was also higher in open sand for Avrainvillea sp. We hypothesize that the dense holdfasts and rhizoids present within the meadow canopy may impede benthic-dwelling or bioturbator species, which accounted for $86 \%$ and $57 \%$ of individuals collected in sand adjacent to $H$. kanaloana and Avrainvillea sp. habitats, respectively. Of the 65 unique species recorded in this study, 16 (25\%) were detected in clove oil stations alone, illustrating the utility of clove-oil 
anesthetic in assessing the diversity and abundance of small-bodied epibenthic fishes. 
1 A Survey of Fishes Associated with Hawaiian Deep-water Halimeda kanaloana

2 (Bryopsidales: Halimedaceae) and Avrainvillea sp. (Bryopsidales: Udoteaceae) Meadows

3

4 Ross C. Langston ${ }^{1}$, Heather L. Spalding ${ }^{2}$

5 'Department of Natural Sciences, University of Hawai'i Windward Community College, 45-720

6 Keaahala Rd., Kāne'ohe, HI 96744

7

8 2Department of Botany, University of Hawai'i at Mānoa, 3190 Maile Way, Room 101, Honolulu, HI 96822

10

11

12

Corresponding Author:

Ross Langston ${ }^{1}$

45-720 Keaahala Rd, Kāne'ohe, HI, 96744

Email address: langston@hawaii.edu 
48 The invasive macroalgal species Avrainvillea sp. and native species Halimeda kanaloana form

expansive meadows that extend to depths of $80 \mathrm{~m}$ or more in the waters off of $\mathrm{O}^{`}$ ahu and Maui, respectively. Despite their wide depth distribution, comparatively little is known about the biota associated with these macroalgal species. Our primary goals were to provide baseline information on the fish fauna associated with these deep-water macroalgal meadows and to compare the abundance and diversity of fishes between the meadow interior and sandy perimeters. Because both species form structurally complex three-dimensional canopies, we hypothesized that they would support a greater abundance and diversity of fishes when compared to surrounding sandy areas. We surveyed the fish fauna associated with these meadows using visual surveys and collections made with clove-oil anesthetic. Using these techniques, we recorded a total of 49 species from 25 families for $H$. kanaloana meadows and surrounding sandy areas, and 28 species from 19 families for Avrainvillea sp. habitats. Percent endemism was $28.6 \%$ and $10.7 \%$, respectively. Wrasses (Family Labridae) were the most speciose taxon in both habitats (11 and six species, respectively), followed by gobies for H. kanaloana (six species). The wrasse Oxycheilinus bimaculatus and cardinalfish Apogonichthys perdix were the most frequently-occurring species within the H. kanaloana and Avrainvillea canopies, respectively. Obligate herbivores and food-fish species were rare in both habitats. Surprisingly, the density and abundance of small epibenthic fishes were greater in open sand than in the meadow canopy. In addition, species richness was also higher in open sand for Avrainvillea sp. We hypothesize that the dense holdfasts and rhizoids present within the meadow canopy may impede benthic-dwelling or bioturbator species, which accounted for $86 \%$ and $57 \%$ of individuals collected in sand adjacent to H. kanaloana and Avrainvillea sp. habitats, respectively. 
70 Of the 65 unique species recorded in this study, $16(25 \%)$ were detected in clove oil stations

71 alone, illustrating the utility of clove-oil anesthetic in assessing the diversity and abundance of

72 small-bodied epibenthic fishes.

\section{INTRODUCTION}

Macroalgal meadows constitute important habitats for reef- and nearshore fish species. Many are important grazing areas for herbivorous fishes (Lobel and Ogden 1981) and may also serve as spawning sites for recreationally important food fishes such as parrotfish and wrasses (Colin and Bell 1991). Macroalgae may also serve a key role in ontogenetic habitat shifts in postsettlement fish (Eggleston 1995, Dahlgren and Eggleston 2000). Relative to surrounding habitats, which are often sandy and of low-relief, macroalgal meadows constitute highly-complex and rugose habitats which may afford protection to juvenile and small-bodied reef fish species alike.

Until recently, most detailed studies of reef fish diversity have been limited to $30 \mathrm{~m}$ or less (e.g., Randall 1998, Greenfield 2003), which is the generally accepted limit for conventional SCUBA diving. However, with the recent advent of Closed Circuit Rebreathers (CCR) and mixed-gas diving technology, properly-trained researchers are now able to work at depths of $100 \mathrm{~m}$ or more (e.g., Pyle 2000, Lesser et al. 2009, Khang et al. 2010, Kane et al. 2014, Kosaki et al., 2016 and Simon et al. 2016). Recent work has focused on the mesophotic zone, which extends from 30$150 \mathrm{~m}$ (Henderstein 2010). Much of this work has focused on coral reef habitats and their associated fauna. Few studies have investigated the fauna of mesophotic macroalgae, despite the fact that several meadow-forming species occur at depths of $50 \mathrm{~m}$ or more in tropical and subtropical waters (Huisman et al. 2007, Spalding 2012, Pyle et al. 2016). 
92 In this paper, we describe the fish fauna associated with two deep-water macroalgal species,

93 Avrainvillea sp. and Halimeda kanaloana, from Hawaiian waters. Avrainvillea sp. and $H$.

94 kanaloana are siphonous green macroalgae which form predominantly monospecific meadows

95 over large areas of sandy substrate from shallow $(1 \mathrm{~m})$ to deep ( $>80 \mathrm{~m})$ waters in the Main

96 Hawaiian Islands (Spalding 2012). Halimeda kanaloana is a calcified alga native to Hawai' $\mathrm{i}$

97 with multiple branched axes up to $30 \mathrm{~cm}$ in height (Verbruggen et al. 2006). Avrainvillea sp., an

98 invasive species that was previously misidentified as A. amadelpha (Wade and Sherwood 2015),

99 forms dense, mat-like beds with bladed canopies approximately $10 \mathrm{~cm}$ in height (Spalding 2012).

100 Avrainvillea sp. first appeared off Kahe Point, O`ahu in 1981, and subsequently spread to

101 Maunalua Bay, O`ahu (Brostoff 1989), where it outcompeted native algae and seagrasses

102 (Peyton 2009, Abbott and Huisman 2004). Both species have been reported to support a greater

103 diversity of epibenthic or infaunal invertebrates when compared to surrounding sandy habitats

104 (Fukunaga 2008; Magalhaes and Bailey-Brock 2014); however, little is currently known about

105 the role these assemblages may play in the creation/loss of unique habitat for fishes. Because

106 Avrainvillea sp. and H. kanaloana occupy similar habitats in Hawai'i (sandy substrate in

107 moderate to low wave environments), they offer an opportunity to determine the effects of

108 canopy type on the composition of the associated fish fauna.

109 Since little information is currently available for these habitats, our primary goal was to provide

110 baseline information on the fish fauna associated these meadows. As part of this goal, we sought

111 to document the most common and abundant species in both habitats. We also sought to identify

112 any commercially- or recreationally important fish species so that resource managers can

113 determine if these meadows merit additional study or protection. Based on surveys from

114 shallow-water meadows (e.g., Lobel and Ogden 1981; Francini-Filho et al., 2010), we 
115 hypothesized that deepwater H. kanaloana and Avrainvillea sp. meadows might be important

116 feeding areas for herbivorous species such as surgeonfishes or parrotfishes, many of which are

117 important food-fish species in Hawai'i. In addition, we also attempted to calculate the level of

118 endemism in both macroalgal habitats. Given that deep reefs in the Northwestern Hawaiian

119 Islands (NWHI) support a greater number of endemic species than their shallow-water

120 counterparts (Kane et al. 2014), we hypothesized that deep water macroalgal meadows might

121 likewise support a greater proportion of endemic species than shallow habitats in the Main

122 Hawaiian Islands (MHI).

123 Our final goal was to compare the abundance and diversity of small-bodied epibenthic fishes

124 between open sand and meadow canopy subhabitats. Because both macroalgal species form

125 structurally complex three-dimensional canopies, we hypothesized that they would support a

126 greater abundance and diversity of fishes when compared to surrounding sandy habitats, which

127 are typically of low relief and complexity. This hypothesis is supported by the work of Chittaro

128 (2004), who found that fish abundance and species richness in Tague Bay, St. Croix were

129 positively correlated with $H$. incrassata habitats and negatively correlated with open sand and

130 pavement. Likewise, Ornellas and Coutinho (1998) found that fish diversity in sublittoral areas

131 of Cabo Frio Island (Brazil) was greater in Sargassum furcatum beds than in surrounding sandy

132 habitats. Thus, it seems likely that H. kanaloana and Avrainvillea meadows should support a

133 greater diversity and abundance of fishes than adjacent sandy areas. 
138 We utilized CCR technical diving to survey fish assemblages during a total of 20 dives (four in 139 Avrainvillea sp. habitats and 16 in H. kanaloana habitats). Avrainvillea sp. habitats were

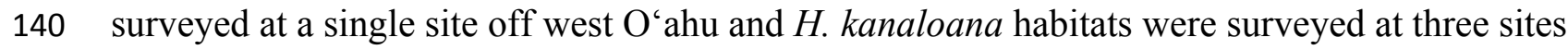

141 off of south and west Maui (Figure 1). All surveys were conducted between June $14^{\text {th }}, 2005$ and 142 June $12^{\text {th }}, 2006$. Initial surveys consisted of visual censuses supplemented by collections made 143 with pole spears. All other surveys were conducted using tandem visual surveys combined with 144 collections using clove-oil anesthetic in order to better assess the numbers of small epibenthic 145 fishes (Figure 2). For these collections, an anesthetic solution of $10 \%$ clove oil in $90 \%$ ethanol 146 was aspirated from a squirt bottle beneath a $1.5 \mathrm{~m}$ weighted plastic tarp. The tarp was placed 147 haphazardly over either sand or canopy. The solution was allowed to work for a period of 10 148 minutes, during which the diver conducted visual- and photographic surveys of larger-bodied 149 fish species (see below). After the 10 minutes had elapsed, the divers removed the weighted tarp 150 and used fine-mesh nets to collect the fishes, which were photographed and preserved in $10 \%$ 151 formalin for subsequent identification. Because fishes caught in the clove oil stations were 152 collected from a known area $(1.5 \mathrm{~m})$, we were able to compare the species richness and 153 abundance (average number of species and individuals per $1.5 \mathrm{~m}$ collection) between sand and 154 canopy sub-habitats. $<<$ Figure 1 near here $>>$ Conventional transect-based visual surveys were impractical given the limited bottom157 time, mobility, and task-load of diver teams. Instead, large-bodied fishes were surveyed using a 158 stationary point count (SPC) in which a diver recorded all fishes that resided or passed through a 
159 visually estimated 10 m cylinder centered on the diver's location (the weighted tarp). The survey

160 time for each SPC was typically 10 minutes. Additional species were collected or surveyed via

161 opportunistic spearfishing and photographs. All fish collections were performed in accordance

162 with a University of Hawaii Institutional Animal Care and Use Protocol (\# 06-058). Permission

163 to use clove oil anesthetic was granted by the Hawaii Department of Land and Natural Resources

164 (Permit \#s PRO 2006-28 and PRO 2007-47).

$165<<$ Figure 2 near here $>>$

166 Data Analysis

167 All specimens were identified to species or lowest-possible taxon and classified as endemic

168 (restricted to the Hawaiian Islands, Midway, and Johnston Atoll) or non-endemic using available

169 references (e.g., Randall 2007 and Mundy 2005). For both clove oil collections and visual

170 surveys, we recorded the abundance $(\mathrm{N})$ of each species as well as the habitat (meadow-forming

171 species) and sub-habitat (canopy or sand \& rubble) where each species was observed or

172 collected. We used this information to calculate the species richness (S) and a Shannon-Wiener

173 diversity index $\left(\log\right.$ e; $\left.\mathrm{H}^{\prime}\right)$ for each sub-habitat. We calculated percentage occurrence $(\% \mathrm{Occ})$ as

174 the proportion of collections made within each sub-habitat in which a species was recorded, and

175 percentage relative abundance (\%RA) as the number of individuals of a species recorded within

176 a sub-habitat divided by the total number of individuals that were collected or observed in that

177 sub-habitat. We follow Randall (1996) in calculating the percent endemism by dividing the

178 number of endemic species by the total number of species present in a particular habitat. We also

179 used available references (Randall 1996, 2007) and personal observations to identify species that

180 reside-upon or feed within the sediment as benthic associates or bioturbators (B) in order to 
181 determine if abundance of these species differed between sub-habitats. For clove oil collections,

182 we estimated the density (D) of fishes collected by dividing the number of individuals of each

183 species by the total area of the substrate that was sampled. We compared the median abundance

$184\left(\mathrm{~N}_{\mathrm{x}}\right)$, density $\left(\mathrm{D}_{\mathrm{x}}\right)$, and species richness $\left(\mathrm{S}_{\mathrm{x}}\right)$ within each sub-habitat using the Mood Median

185 Test, as the resulting data did not meet the assumptions necessary to use parametric statistical

186 tests.

RESULTS

We conducted a total of 14 visual surveys and 51 tandem surveys (visual surveys + collections using clove oil anesthetic) in Avrainvillea sp. and H. kanaloana habitats (Table 1).

Percent occurrence and relative abundance of fishes in $\mathrm{H}$. kanaloana meadows

A total of 49 species from 25 families were recorded from H. kanaloana meadows and surrounding sandy areas (Table 2). Overall species richness and diversity were nominally greater in canopy $\left(\mathrm{S}=31\right.$ species, $\left.\mathrm{H}^{\prime}=2.523\right)$ than in open sand $\left(\mathrm{S}=29\right.$ species, $\left.\mathrm{H}^{\prime}=2.064\right)$.

Gobies. Wrasses were also the most abundant taxon within meadow canopy, accounting for

$54.8 \%$ of individuals collected or observed. In contrast, gobies comprised only $15.9 \%$ of individuals surveyed in the H. kanaloana canopy. The most abundant and frequently-occurring species within meadow canopy was the Two-spot wrasse, Oxycheilinus bimaculatus. Other commonly-occurring species included the goby, Gnatholepis spp., and the wrasses 

goby species $($ Total $\% \mathrm{RA}=56.9 \%$ ), whereas wrasses only accounted for $4.9 \%$ of individuals surveyed within this sub-habitat. The three most commonly-occurring species were gobies: Gnatholepis spp., Opua nephodes, and Psilogobius mainlandi.

$<<$ Table 2 near here $>>$

Percent occurrence and relative abundance of fishes in Avrainvillea sp. meadows

A total of 28 species from 19 families were recorded from Avrainvillea meadows and adjacent by two species or fewer. Apogonichthys perdix. This species was recorded only from clove oil collections and was never observed in visual surveys. Other common species found in Avrainvillea sp. canopy include the wrasses $O$. bimaculatus and Pseudocheilinus evanidus. The two most abundant species were the unicorn fish Naso caesius and Hawaiian Flame Wrasse, Cirrhilabrus jordani, however, these species were recorded from a single collection each.

222 Overall, wrasses were the most abundant taxon in open sand ( $\% \mathrm{RA}=23.3 \%)$. The most

223 frequently-occurring species was the wrasse $O$. bimaculatus, followed by the sandperch 224 Parapercis schauinslandii, which was also the most abundant species.

$225<<$ Table 3 near here $>>$ 
227 Abundance, species richness, and diversity of epi-benthic fishes from clove oil anesthetic

228 collections

229

230

231

232

233

234

235

236

237

238

239

240

241

242

243

244

245

246

247

248

249

A total of 105 individuals from 19 species were collected from H. kanaloana habitats using clove oil anesthetic (Table 4). The eyebar goby, Gnatholepis anjerensisand wrasse $O$.

bimaculatus, were the most abundant and frequently-collected species in H. kanaloana canopy. In contrast, the cloud goby, Opua nephodes, and Hawaiian shrimp goby Psilogobius mainlandi were the most abundant fishes in in open sand, and were rarely collected from meadow canopy. The median abundance and density of fishes was significantly higher in open sand $\left(\mathrm{N}_{\mathrm{x}}=\right.$ 4.00 individuals/collection, $\mathrm{D}_{\mathrm{x}}=2.67$ fish per $\left.\mathrm{m}^{2}\right)$ when compared to the meadow canopy $\left(\mathrm{N}_{\mathrm{x}}\right.$ $=1.00, \mathrm{D}_{\mathrm{x}}=0.67$; Chi-Square $=13.41, \mathrm{DF}=1, \mathrm{P}=0.000$ for both tests). Total species richness was also nominally higher in open sand (15 vs. 10 species); however, median species richness did not differ significantly between sub-habitat types $($ Chi-Square $=0.63, \mathrm{DF}=1, \mathrm{P}=0.426)$. We calculated Shannon Weiner Diversity Index values of 2.2474 and 1.5013, respectively for open sand and canopy.

$<<$ Table 4 near here $>>$

A total 16 species and 42 individuals were collected from Avrainvillea sp. sub-habitats using clove oil anesthetic (Table 5). The cardinalfish Apogonichthys perdix was the most abundant species collected from Avrainvillea canopy whereas the sandperch Parapercis schauinslandii was most abundant species collected in open sand.

As with collections made in H. kanaloana meadows, fishes from Avrainvillea collections were more abundant and densely-distributed within open sand $\left(\mathrm{N}_{\mathrm{x}}=7.00\right.$ individuals/collection, $\mathrm{D}_{\mathrm{x}}=4.67$ fish per $\left.\mathrm{m}^{2}\right)$ when compared to meadow canopy $\left(\mathrm{N}_{\mathrm{x}}=2.50, \mathrm{D}_{\mathrm{x}}=1.67\right.$; Chi-Square $=11.00, \mathrm{DF}=1, \mathrm{P}=0.001$ for both tests). Median Species Richness was also significantly 
250 greater in open sand $\left(\mathrm{S}_{\mathrm{x}}=6.00\right.$ species/collection) when compared to meadow canopy $\left(\mathrm{S}_{\mathrm{x}}=\right.$

251 2.00; Chi-Square $=11.00, \mathrm{DF}=1, \mathrm{P}=0.001)$. The Shannon Weiner Diversity Index was

252 likewise higher in open sand $\left(H^{\prime}=2.3667\right)$ vs. meadow canopy $\left(H^{\prime}=1.4383\right)$.

$253<<$ Table 5 near here $>>$

\section{Discussion}

255 Deep-water Avrainvillea sp. and H. kanaloana meadows form complex three-dimensional

256 habitats in an otherwise two-dimensional sandy environments. This structure provides habitat

257 and shelter for numerous fish species. Of the two habitat types, H. kanaloana was most diverse

258 supporting a total of 49 species from 25 fish families. In contrast, Avrainvillea sp. meadows

259 contained 28 species from 19 families, though it is likely that the lower numbers for this species

260 may be due to the lower sample size for this species. Within-canopy diversity (H') was

261 nominally greater for $H$. kanaloana (2.52) than Avrainvillea sp. (1.87). In comparison,

262 Friedlander and Parrish (1998) estimated that fish diversity on a shallow Kauai reef ranged

263 between 1.72 to 2.54 . Therefore, it would appear that the diversity of these deep-water

264 macroalgal meadows is similar to that of shallow Hawaii reefs.

265 Wrasses (Family Labridae) were the most speciose taxon in both habitats (11 and six

266 species, respectively), followed by gobies for $H$. kanaloana (six species). The wrasse

267 Oxycheilinus bimaculatus and cardinalfish Apogonichthys perdix were the most frequently-

268 occurring species within the H. kanaloana and Avrainvillea canopies, respectively. These

269 species were considerably less common and abundant in open sand, indicating as strong habitat

270 preference for the meadow canopy. Other common species that showed strong associations with

271 meadow canopy include the toby, Canthigaster jactator (H. kanaloana) and the wrasses

272 Cymolutes lecluse and C. praetextatus (H. kanaloana) and Pseudojuloides cerasinus (both 
273 species). With the exception of $A$. perdix, which is nocturnal, we observed each of these species

274 actively foraging within the meadow canopy on numerous occasions. Thus, meadow canopy

275 appears to be an essential habitat for these species.

276 Most of the other common species were epibenthic sand-dwellers (e.g., gobies,

277 dragonettes, sandperch, and flatfishes). Many of these species also occur in sandy areas near

278 coral reefs (see Greenfield, 2003). In most cases, these species were actually more abundant in

279 open sand rather than canopy (Tables $2 \& 3$ ), suggesting that their association with the meadows

280 is incidental rather than a result of any inherent habitat preference.

\section{Percent Endemism}

282 We estimate the percent endemism for fishes living in H. kanaloana and Avrainvillea habitats

283 (including adjacent sandy areas) to be $28.6 \%$ and $10.7 \%$, respectively. Given that approximately

$28425 \%$ of Hawaii's fish species are considered to be endemic (Randall 2007), H. kanaloana

285 meadows harbor a slightly greater proportion of endemic species than would be expected by

286 chance. In comparison, approximately $46 \%$ of fishes surveyed within mesophotic depths in the

287 NWHI are endemic (Kane et al., 2014), and endemism may reach 100\% in some areas (Kosaki et

288 al., 2016). Thus, compared to mesophotic habitats in the NWHI, these macroalgal meadows

289 have proportionally fewer endemic species. We speculate that the nominally higher endemism

290 documented for $H$. kanaloana habitats could be a result of coevolution; $H$. kanaloana is native to

291 Hawai 'i, with the largest meadows reported from the Maui-Nui complex (Spalding 2012). It is

292 possible that some of these endemic fish species may have evolved a commensal relationship

293 with the alga. Although only five of the 14 endemic species regularly reside in H. kanaloana

294 meadows, it is possible that some of the sand-dwelling endemics may occasionally dart into the

295 canopy to avoid predators or may opportunistically exploit the new habitat created when 
296 blowouts (barren areas) are formed by the scour of winter swells. In contrast, Avrainvillea sp. is

297 an invasive species which was first reported off Kahe Point, O`ahu in 1981 (Brostoff 1989).

298 This species supports only three endemic species, with two (C. jordani and Bodianus

299 albotaeniatus) recorded from canopy and one (Aseraggodes borehami) recorded from open sand.

300 Given its supposed recent arrival, it is possible that endemic fish species have had less time to

301 adapt to this unique habitat.

302 Abundance of Herbivores and Food fish

303 Contrary to our hypothesis that H. kanaloana and Avrainvillea sp. meadows may serve as

304 foraging grounds for herbivorous fish species, we found that obligate herbivores were quite rare

305 in both meadow types and were represented by only two species: the angelfish Centropyge

306 fisheri (H. kanaloana) and the surgeonfish Acanthurus blochii (Avrainvillea sp.). Neither

307 species was common or abundant, nor do they feed on macroalgae. Centropyge fisheri is an

308 obligate herbivore (Thresher and Collin 1986) that likely feeds on turf algae, whereas A. blochii

309 typically feeds primarily on benthic algae on reefs or algal films covering sand (Randall 2005).

310 Surprisingly, parrotfishes (Family Scaridae) and Blennies (Family Bleniidae) were completely

311 absent from the deepwater meadows, despite the fact that we have observed them in shallow-

312 water (<1 m) Avrainvillea sp. meadows (R. Langston, Pers. Obs). Six species (Rhinecanthus

313 aculeatus, Aluterus scriptus, Ostracion meleagris, Arothron hispidus, Canthigaster jactator, and

314 C. coronata) from H. kanaloana meadows and two from Avrainvillea sp. meadows (A. hispidus

315 and C. coronata) are reported to be omnivorous, and occasionally consume algae. However,

316 given their small size and limited abundance, it is unlikely that they consume significant amounts

317 of macroalgal biomass. These results corroborate the work of Spalding (2012) who found little

318 evidence of feeding scars on plants collected from deep-water H. kanaloana meadows. The 
319 absence of herbivores in these habitats may, in part, be due to their extreme depths. Several

320 studies (e.g., Brokovich et al., 2010, Fukunaga et al., 2016, Larkum et al., 1967 and Thresher

321 and Colin, 1986) report that herbivorous fish species are rare below $30 \mathrm{~m}$. In addition, the lack

322 of herbivory may be due to the low digestibility of the algae; both Avrainvillea sp. and Halimeda

323 sp. contain numerous compounds which may deter herbivory (Meyer et al. 1994; Hay et al.

324 1990; Paul and van Alstyne 1992). In addition, the partial calcification of H. kanaloana may

325 serve as an added impediment to herbivory (Schupp and Paul 1994).

326 Commercially- or recreationally-important food-fish species were likewise rare in

327 surveys of either meadow habitat. Three species each were recorded from H. kanaloana (Caranx

328 melampygus, Aprion virescens, and Mulloidichthys sp.) and Avrainvillea sp. habitats (Caranx

329 lugubris, Parupeneus multifasciatus, and A. virescens), however, each of these records was

330 based on a single individual (Tables 2 and 3). In contrast, our surveys do indicate that deep-water

331 Avrainvillea sp. meadows may be an important habitat for the flame wrasse, C. jordani, which is

332 important in the Hawai'i aquarium fish trade. According to Walsh et al. (2003), commercial

333 fishers in the state reported catches of 13,919 C. jordani between the years1976 and 2003. They

334 estimated total wholesale value for the catch to be $\$ 133,116$. Based on our review of two online

335 fish sellers (liveaquaria.com and petsolutions.com- July 2016), C. jordani retails for \$130

336 (juvenile female) to $\$ 300$ (adult male) each. Assuming the extraordinary price of $C$. jordani is a

337 result of high demand among aquarium enthusiasts, it is possible that aquarium fishers may

338 eventually target deep-water Avrainvillea sp. meadows as a potential source for this species. 339

340 
341

342 collections

343 Our clove oil surveys detected significantly higher abundances and densities of epibenthic fishes

344 in open sand when compared to meadow canopy for both H. kanaloana and Avrainvillea sp.

345 Median species richness was also significantly higher in sand vs. meadow canopy for

346 Avrainvillea sp., and diversity ( $\left.\mathrm{H}^{\prime}\right)$ was nominally higher in open sand for both species. These

347 results are surprising given that several studies (e.g., Chittaro 2004; Omena and Creed 2004; and

348 Ornellas and Coutinho 1998) have documented that diversity and abundance of fishes and

349 invertebrates are usually highest within meadow canopy. Moreover, two recent surveys of the

350 invertebrate fauna of H. kanaloana and Avrainvillea sp. meadows further support this

351 hypothesis. Magalhaes and Bailey-Brock (2014) found that infaunal polychaetes were

352

353

354

355

356

357

358

359

360

361

362

363

considerably more abundant and diverse in shallow Avrainvillea meadows, when compared to

adjacent sandy areas. Fukunaga (2008) likewise found that polychaetes were more abundant and diverse within $H$. kanaloana canopy. She also reported that epibenthic invertebrates were more diverse and speciose within meadows, but that abundance did not differ significantly between the two sub-habitats.

It is possible that the greater abundance of fishes in open sand may, in part, reflect a sampling bias. Fish inhabiting dense canopy are more likely to be overlooked by visual surveys when compared to individuals occurring on bare sand. Similarly, fish anesthetized in clove oil stations are more easily recovered in bare sediment than in dense canopy (this is particularly true for Avrainvillea sp. meadows given their dense, bladed morphology). Alternatively, it is possible that the greater abundance of some species on open sand may be related to differences in habitat preference or sediment composition between vegetated and non-vegetated areas. For 
364 example, within Halimeda kanaloana meadows, the Hawaiian shrimp goby, P. mainlandi was

365 collected almost exclusively on bare sediment. This species lives in burrows constructed by the

366 snapping shrimps, Alpheus rapax and A. rapicida (Randall, 2007). In a concomitant study of the

367 epibenthic invertebrates from the same H. kanaloana meadows, Fukunaga (2008) recorded a

368 total of 131 A. rapax in sand patches and only three individuals within the meadow canopy.

369 Given this, it is not surprising that $P$. mainlandi was also rare within meadow canopy; without

370 the presence of its invertebrate symbiont, the goby would have a difficult time finding shelter.

371 We believe that the dearth of $A$. rapax burrows within meadow canopy may be related to sub-

372 surface algal growth. Each H. kanaloana plant has a large, bulbous holdfast over $8 \mathrm{~cm}$ in length

373 that penetrates deeply into the substrate, forming a network of stringy rhizoids that extend out

374 into the surrounding sediment (Verbruggen et al. 2006). In addition, most H. kanaloana

375 meadows contain several hundred plants per $\mathrm{m}^{-2}$ (Spalding 2012), thus forming a dense

376 concentration of rhizoids and holdfasts in the sediment that may be difficult for burrow-forming

377 species, such as A. rapax, to penetrate. In contrast, Avrainvillea has a dense and spongy holdfast

378 that forms a terraced, penetrating mat over the sediment (Huisman et al. 2007). These mats

379 sequester fine sediments under their holdfast, forming anoxic mounds of sediment (Littler et al.

380 2005). It is possible that these structures may likewise negatively impact benthic-dwelling and

381 bioturbator speces. Other published studies support this hypothesis. For example, Milazzo et al.

382 (2004) found that numbers of Bucchich's goby, Gobius bucchichi increased significantly in plots

383 where the algal biomass was experimentally reduced. This feeds primarily on benthic mollusks

384 and prefers open sandy habitats (Fasola et al. 1997). Thus, it is not surprising that its abundance

385 would increase when more suitable habitat was made available through the algal removal

386 experiments. Neira et al. (2005) likewise documented a similar shift in the invertebrate 
387 macrofauna for tidal flats invaded by a hybrid cordgrass. They found that the densities of

388 macroinvertebrates were $75 \%$ lower in the vegetated flats, when compared to un-vegetated areas,

389 and that species richness was also lower in the vegetated areas. Although we did not

390 experimentally manipulate the algal biomass in this study, it does appear that benthic-dwelling

391 and bioturbator species are numerically more abundant in open sand. Within H. kanaloana

392 habitats (Table 4), these species accounted for $86 \%$ of individuals collected within open sand vs.

$39361 \%$ collected meadow canopy. A similar relationship is evident for Avrainvillea sp. collections

394 (Table 5); 57\% of individuals collected from open sand were from benthic-dwelling or

395 bioturbator species, whereas only five percent of those collected from canopy were classified as

such. Thus, we suggest that the presence of surface- and subsurface algal growths may

397

negatively impact the abundance and diversity of small epi-benthic fishes by reducing the amount of favorable habitat and feeding areas utilized by these species.

Advantage of Clove Oil Collections

401 The use of clove oil anesthetic greatly enhanced our ability to estimate the fish diversity within

402 H. kanaloana and Avrainvillea sp. meadows. Of the 65 unique species recorded in this study, 16

$403(25 \%)$ were detected only in clove oil stations alone. Thus, the use of clove oil anesthetic

404 increased our overall estimate of species richness by $32.7 \%$. It also enabled us to more

405 accurately estimate the abundance and species richness of small-bodied fishes (gobies, scorpion

406 fishes, cardinalfishes, dragonettes, and small wrasses), many of which are difficult to identify to

407 species without the use of a dissecting scope. In some cases, species collected with clove oil but

408 missed by visual surveys were also quite common. For instance, the cardinalfish Apogonichthys

409 perdix was found to be the most frequently-occurring species in Avrainvillea sp. canopy (Table 
4103 ) though, due to its cryptic coloration and nocturnal nature, it was never observed in visual

411 surveys. In a related study, Fukunaga (2008) measured the diversity and abundance of

412 epibenthic invertebrates within $H$. kanaloana meadows using both visual surveys and clove-oil

413 collections. She recorded 15 species of invertebrates in the visual surveys and 20 additional

414 species in the clove-oil surveys. In this case, the use of clove oil anesthetic increased her ability

415 to detect small epibenthic invertebrates by 133\%. Together, these data highlight the utility of

416 anesthetics (or ichthyocides) in estimating the diversity and abundance of small-bodied fishes

417 and epibenthic invertebrates.

418

419 Acknowledgements

420 We are grateful to D. Pence, A. Fukunaga, S. Hau, K. Peyton, and C. Stobeneau for assistance

421 with field surveys and logistical support. Small boat support was kindly provided by the Hawai' $\mathrm{i}$

422 Department of Aquatic Resources, Department of Land and Natural Resources on Maui.

423

424

425

426

427

428

429

430

431

432

433 
434

435

436

437

438

439

440

441

442

443

444

445

446

447

448

449

450

451

452

453

454

455

456

457

458

459

460

461

462

463

464

465

466

467

468

469

470

471

472

473

474

475

\section{Literature Cited}

Abbott IA, Huisman JM. 2004. Marine green and brown algae of the Hawaiian Islands. Honolulu, Hawaii: Bishop Museum Press.

Brokovich E, Ayalon I, Einbinder S, Segev N, Shaked Y, Genin A, Kark S, Kiflawi M. 2010. Grazing pressure on coral reefs decreases across a wide depth gradient in the Gulf of Aqaba, Red Sea. Marine Ecology Progress Series 399:69-80.

Brostoff WN. 1989. Avrainvillea amadelpha (Codiales, Chlorophyta) from O`ahu, Hawai‘i. Pacific Science 43:166-69.

Chittaro PM. 2004. Fish-hanitat associations across multiple spatial scales. Coral Reefs. 23:235-244. DOI 10.1007/s00338-004-0376-z

Colin PL, Bell LJ. 1991. Aspects of the spawning of labrid and scarid fishes (Pisces:

Labroidei) at Enewetak Atoll, Marshall Islands with notes on other families. Environmental Biology of Fishes 31:229-60.

Dahlgren CP, Eggleston DB. 2000. Ecological processes underlying ontogenetic habitat shifts in a coral reef fish. Ecology 81:2227-2240.

Eggleston DB. 1995. Recruitment in Nassau grouper Epinephelus striatus: post-settlement abundance, microhabitat features, and ontogenetic habitat shifts. Marine Ecology Progress Series 124:9-22.

Friedlander AM, Parrish JD. 1998. Habitat characteristics affecting fish assemblages on a Hawaiian coral reef. J. Exp. Mar. Biol. Ecol. 224:1-30.

Fukunaga A. 2008. Invertebrate community associated with the macroalga Halimeda kanaloana meadow in Maui, Hawaii. International Review Hydrobiology 93(3):328-341.

Fukunaga A, Kosaki RK, Wagner D, Kane C. 2016. Structure of mesophotic reef fish assemblages in the Northwestern Hawaiian Islands. PLoS ONE 11(7): e0157861. Doi:10.1371/journal.pone.0157861.

Fasola M, Canova L, Foschi F, Novelli O, Bressan M. 1997. Resource use by a Mediterranean rocky slope fish assemblage. Marine Ecology 18(1):51-66.

Francini-Filho R, Ferreira C, Coni E, De Moura R, Kaufman, L. 2010. Foraging activity of roving herbivorous reef fish (Acanthuridae and Scaridae) in eastern Brazil: Influence of resource availability and interference competition. J. Mar. Biol. Assoc. U.K. 3:481-492.

doi:10.1017/S0025315409991147

Greenfield DW. 2003. A survey of the small reef fishes of Kaneohe Bay, Oahu, Hawaiian Islands. Pacific Science 57(1):45-76. 
476 Hay ME, Paul VJ, Renaud PE, Fenical W. 1990. Specialist herbivores reduce their

477 susceptibility to predation by feeding on the chemically defended seaweed Avrainvillea

478 longicaulis. Limnol. Oceanogr. 35(8):1734-1743.

479

480

Hinderstein LM, Marr JCA, Martinez FA, Dowgiallo MJ, Puglise KA, Pyle RL, Zawada GG, Appeldoorn R. 2010. Theme section on "Mesophotic coral ecosystems: characterization, ecology, and management”. Coral Reefs 29:247-51.

Huisman JM, Abbott IA, Smith CM. 2007. Hawaiian reef plants. Honolulu, Hawaii: University of Hawaii Sea Grant College Program.

Kane C, Kosaki K, Wagner D. 2014. High levels of mesophotic reef fish endemism in the Northwestern Hawaiian Islands. Bulletin Marine Science 90(2)693-703.

Kosaki RK, Pyle RL, Leonard JC, Hauk BB, Whitton RK, Wagner D. 2016. 100\% endemism in mesophotic reef fishes assemblages at Kure Atoll, Hawaiian Islands. Mar. Biodiv.DOI 10.1007/s12526-016-0510-5.

Khang SE, Garcia-Sais JR, Spalding HL, Brokovich E, Wagner D, Weil E, Hinderstein L, Toonen RJ. 2010. Community ecology of mesophotic coral reef ecosystems. Coral Reefs 29:255-275.

Larkum AWD, Drew EA, Crossett RN. 1967. The vertical distribution of attached marine algae in Malta. Journal Ecology 55:361-71.

Lesser MP, Slattery M, Leichter JJ. 2009. Ecology of mesophotic coral reefs. Journal Experimental Marine Biology Ecology 375:1-8.

Littler MM, Littler DS, Brooks BL. 2005. Extraordinary mound building Avrainvillea (Chlorophyta): the largest tropical marine plants. Coral Reefs 24: 555-555.

Lobel PS, Ogden JC. 1981. Foraging by the herbivorous parrotfish Sparisoma radians. Marine Biology 64:173-83.

Magalhaes WF, Bailey-Brock JH. 2014. Polychaete assemblages associated with the invasive green alga Avrainvillea amadelpha and surrounding bare sediment patches in Hawaii. Memoirs Museum Victoria 71:161-168.

Meyer KD, Paul VJ, Sanger HR, Nelson SG. 1994. Effects of seaweed extracts and secondary metabolites on feeding by the herbivorous surgeonfish Naso lituratus. Coral Reefs 13:105-12.

Milazzo M, Badalamenti F, Riggio S, Chemello R. 2004. Patterns of algal recovery and smallscale effects of canopy removal as a result of human trampling on a Mediterranean rocky shallow community. Biological Conservation 117:191-202. 
522 Mundy BC. 2005. Checklist of the fishes of the Hawaiian Archipelago. Honolulu, Hawaii:

523 Bishop Museum Press.

524

525

526

527

528

529

530

531

532

533

534

535

536

537

538

539

540

541

542

543

544

545

546

547

548

549

550

551

552

553

554

555

556

557

558

559

560

561

562

563

564

565
Neira C, Levin LA, Grosholz ED. 2005. Benthic macrofaunal communities of three sites in San Francisco Bay invaded by hybrid Spartina, with comparison to uninvaded habitats. Marine Ecology Progress Series 292: 111-126.

Omena E, Creed JC. 2004. Polychaete fauna of seagrass beds (Halodule wrightii Ascherson) along the coast of Rio de Janeiro (Southeast Brazil). Marine Ecology 25:273-288.

Ornellas AB, Coutinho R. 1998. Spatial and temporal patterns of distribution and abundance of a tropical fish assemblage in a seasonal Sargassum bed, Cabo Frio Island, Brazil. J. Fish. Biol. 53:198-208. doi:10.1111/j.1095-8649.1998.tb01027.x

Paul VJ, van Alstyne KL. 1992. Activation of chemical defenses in the tropical green algae Halimeda spp. Journal Experimental Marine Biology Ecology 160:191-203.

Peyton KA. 2009. Aquatic invasive species impacts in Hawaiian soft sediment habitats. Ph.D. dissertation. University of Hawaii at Manoa.

Pyle RL. 2000. Assessing undiscovered fish biodiversity on deep coral reefs using advanced selfcontained diving technology. Marine Technology Society Journal 34:82-91.

Pyle RL, Boland R, Bollick H, Bowen BW, Bradley CJ, Kane C, Kosaki RK, Langson R, Longenecker K, Montgomery AD, Parrish FA, Popp BN, Rooney J, Smith CM, Wagner D, Spalding HL. 2016. A comprehensive investigation of mesophotic coral ecosystems in the Hawaiian Archipelago. PeerJ 4: e2475. DOI: https://doi.org/10.7717/peerj.2475

Randall, JE. 1996. Shore fishes of Hawaii. Natural World Press.

Randall JE. 1998. Zoogeography of shore fishes in the Indo-Pacific region. Zoological Studies Taipei 37:227-268.

Randall JE. 2005. Reef and shore fishes of the South Pacific. Honolulu, Hawaii: University of Hawaii Press.

Randall JE. 2007. Reef and shore fishes of the Hawaiian Islands. Honolulu, Hawaii: Sea Grant College Program.

Randall JE, Langston RC, Severns M. 2006. First record of the Labrid fish Cymolutes praetextatus from the Hawaiian Islands. Pacific Science 60(4):549-553.

Schupp PJ, Paul VJ. 1994. Calcium carbonate and secondary metabolites in tropical seaweeds: variable effects on herbivorous fishes. Ecology 75(4):1172-1185.

Simon T, Pinheiro HT, Moura RL, Carvalho-Filho A, Rocha LA, Martins AS, Mazzei E, Francini-Filho RB, Amado-Filho GM, Joyeux JC. 2016. Mesophotic fishes of the Albrolhos 
566 Shelf, the largest reef ecosystem in the South Atlantic. Journal of Fish Biology DOI:

$56710.1111 / \mathrm{jfb} 12967$.

568

569 Spalding HL. 2012. Ecology of mesophotic macroalgae and Halimeda kanaloana meadows in

570 the Main Hawaiian Islands. Ph.D. Diss. University of Hawaii at Manoa.

571

572 Thresher RE, Colin PL. 1986. Trophic structure, diversity and abundance of fishes of the deep

573 reef (30-300 m) at Enewetak, Marshall Islands. Bull. Mar. Sci. 38(1):253-272.

574

575

Verbruggen H, De Clerck O, N'Yeurt ADR, Spalding H, Vroom PS. 2006. Phylogeny and

576 taxonomy of Halimeda incrassata, including descriptions of H. kanaloana and H. heteromorpha

577 spp. nov. (Bryopsidales, Chlorophyta). European Journal of Phycology 41: 337-362

578

579

Wade RM, Tang Y, Sherwood AR. 2015. Morphological and molecular assessment of

580

Avrainvillea (Ulvophyceae, Chlorophyta) and implications for invasive species management. $\mathrm{p}$.

581

17 In: 50 ${ }^{\text {th }}$ Annual Meeting of the Phycological Society of America, 10-13 August 2015,

582

583

584

Philadelphia, PA.

585

Walsh WA, Cotton SSP, Dierking J, Williams I. 2003. The commercial marine aquarium fishery

586 in Hawaii 1976-2003. In: Status of Hawaii's Coastal Fisheries in the New Millennium

587

Proceedings of the 2001 Fisheries Symposium American Fisheries Society, Hawai'i Chapter.

588

589

590

591

592 
Figure 1

Map of the Main Hawaiian Islands showing the locations of the four survey sites.

Avrainvillea sp. meadows were surveyed off west Oahu. Halimeda kanaloana meadows were surveyed off south and west Maui.

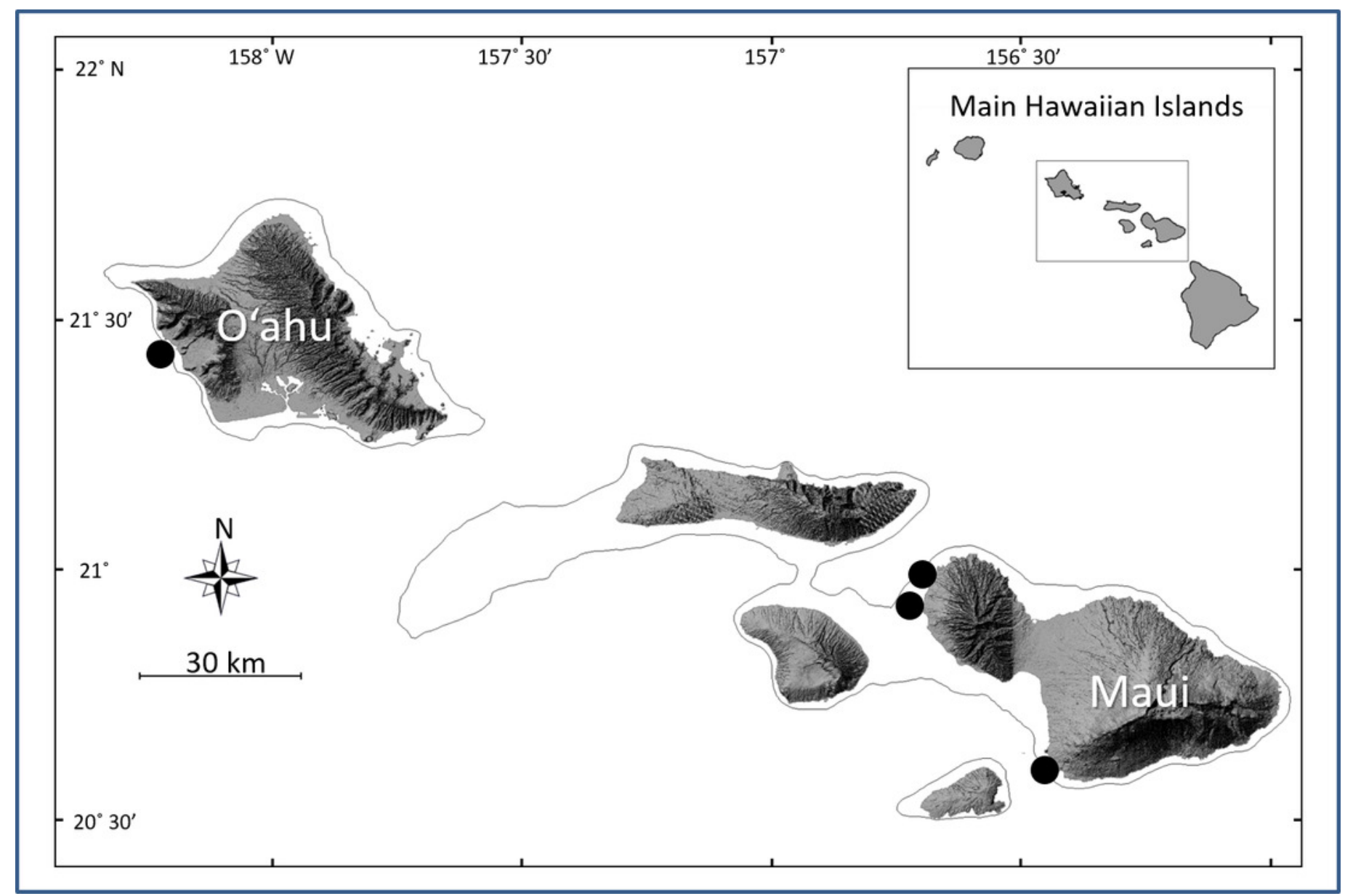




\section{Figure 2}

Survey techniques used in Halimeda kanaloana (A-D) and Avrainvillea sp. meadows.

Large-bodied species were surveyed visually (A) or photographically (B). Unidentified species were collected with small spears (C). Small-bodied epibenthic fishes were surveyed by injecting a clove-oil solution under a $1.5 \mathrm{~m}$ weighted tarp (D). The anesthetized fishes were collected with fine-mesh nets and preserved for subsequent identification. Diver conducting a visual survey of Avrainvillea sp. meadow (E). Note the denser canopy.

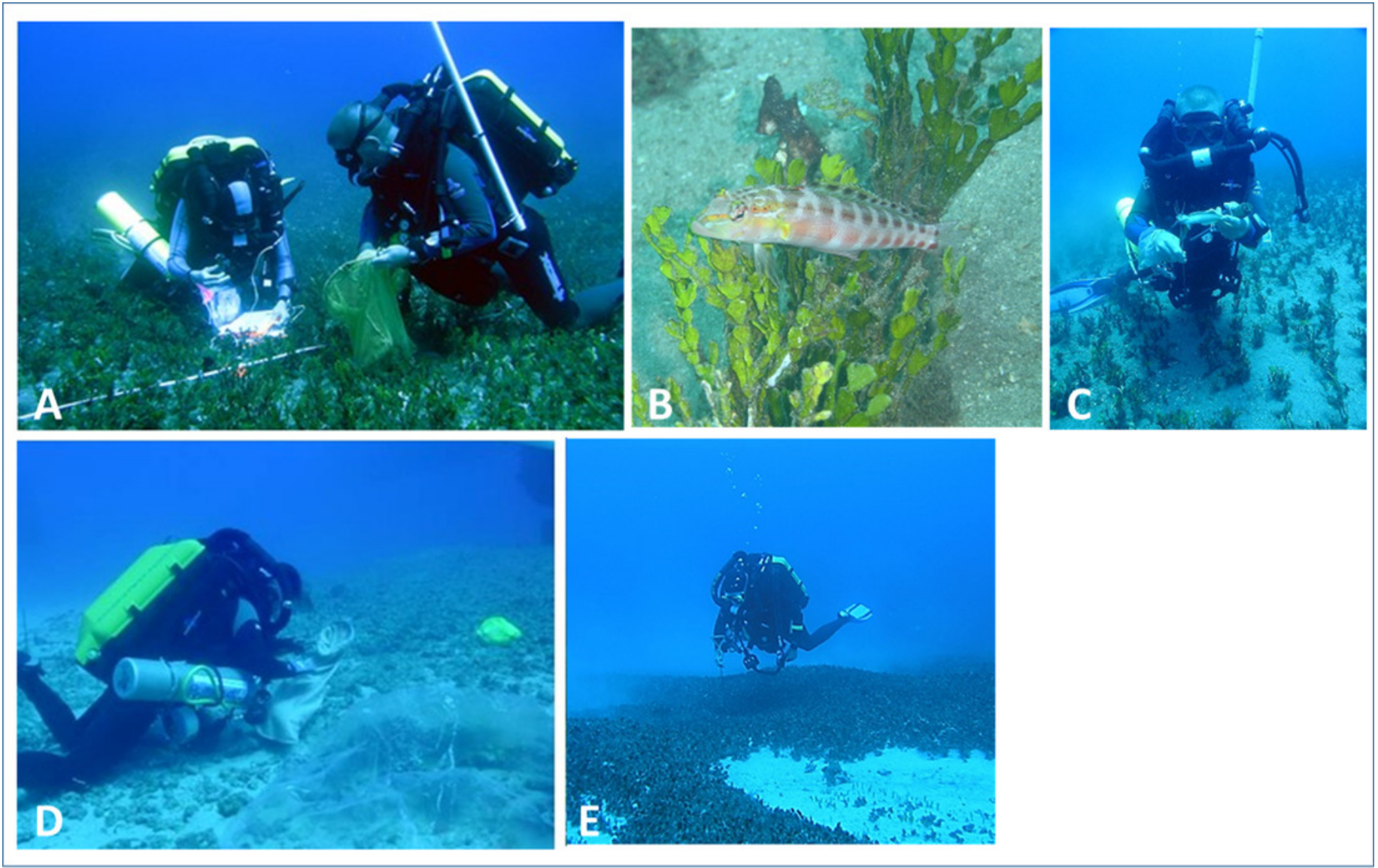




\section{Table $\mathbf{1}$ (on next page)}

Summary of visual surveys and tandem visual+clove-oil collections by habitat type and location. 
1 Table 1. Summary of visual surveys and tandem (visual+clove-oil) collections by habitat type and location.

\begin{tabular}{|c|c|c|c|c|}
\hline \multirow[b]{2}{*}{ Survey Type } & \multicolumn{2}{|c|}{ Avrainvillea sp. } & \multicolumn{2}{|c|}{ Halimeda kanaloana } \\
\hline & Canopy & Sand/Rubble & Canopy & $\underline{\text { Sand/Rubble }}$ \\
\hline Visual Only & 2 & 0 & 8 & 4 \\
\hline Clove Oil + Visual & 8 & 3 & 28 & 12 \\
\hline Depth Range & & & & $\mathrm{m}$ \\
\hline Dates & & $6 / 12 / 2006$ & & $5 / 23 / 06$ \\
\hline \multicolumn{5}{|l|}{$\begin{array}{l}\text { Collection } \\
\text { Locations }\end{array}$} \\
\hline & \multicolumn{2}{|c|}{$\begin{array}{c}\text { Makaha, Oahu } \\
21^{\circ} 26^{\prime} 50.22^{\prime \prime N} 158^{\circ} 12^{\prime} 42.24^{\prime \prime} \mathrm{W}\end{array}$} & \multicolumn{2}{|c|}{$\begin{array}{c}\text { Kahekili Beach Park, Maui } \\
20^{\circ} 56^{\prime} 14.33^{\prime N} 156^{\circ} 41^{\prime} 40.54 " \mathrm{~W} \\
\text { Honokowai Beach Park, Maui } \\
20^{\circ} 57^{\prime} 21.00^{\prime N} 156^{\circ} 41^{\prime} 19.96^{\prime \prime} \mathrm{W} \\
\text { Makena Beach Park, Maui } \\
20^{\circ} 37^{\prime} 42.35^{\prime \prime N} 156^{\circ} 27^{\prime} 15.04^{\prime \prime W}\end{array}$} \\
\hline
\end{tabular}

2

3

4

5

6

7

8

9

10

11

12

13

14 


\section{Table 2 (on next page)}

Checklist of fishes associated with deep-water Halimeda kanaloana meadows based on clove oil collections and visual surveys.

Sub-habitats are listed as Meadow Canopy (directly within vegetation) and Sand/Rubble (blow-outs and sandy meadow perimeters). Endemic species are indicated by "E" whereas those which rest directly upon- or feed within the substrate are indicated by "B". $C O(N)$ and $\mathrm{V}(\mathrm{N})$ indicate the numbers of each species collected or surveyed in clove oil collections or visual surveys, respectively. All other abbreviations are described in the methods. 
1 Table 2. Checklist of fishes associated with deep-water Halimeda kanaloana meadows based on clove oil collections and visual surveys. Sub-habitats are listed as Meadow Canopy (directly within vegetation) and Sand/Rubble (blow-outs and sandy \& meadow perimeters). Endemic species are indicated by "E" whereas those which rest directly upon- or feed within the substrate are indicated by "B". $\mathrm{CO}(\mathrm{N})$ and $\mathrm{V}(\mathrm{N})$ indicate the numbers of each species collected or surveyed in clove oil collections or visual surveys, respectively. All other abbreviations are described in the methods.

\begin{tabular}{|c|c|c|c|c|c|c|c|c|c|}
\hline \multirow[b]{2}{*}{ Species } & \multirow[b]{2}{*}{$\mathrm{E}, \mathrm{B}$} & \multicolumn{4}{|c|}{ Meadow Canopy } & \multicolumn{4}{|c|}{$\underline{\text { Sand/Rubble }}$} \\
\hline & & $\mathrm{CO}(\mathrm{N})$ & $\mathrm{V}(\mathrm{N})$ & $\%$ Occ & $\%$ RA & $\mathrm{CO}(\mathrm{N})$ & $\mathrm{V}(\mathrm{N})$ & $\% \mathrm{Occ}$ & $\%$ RA \\
\hline \multicolumn{10}{|l|}{ Myliobatidae } \\
\hline Aetobatus narinari & & & & & & & 1 & 6.3 & 0.2 \\
\hline Manta birostris & & & & & & & 1 & 6.3 & 0.2 \\
\hline \multicolumn{10}{|l|}{ Congridae } \\
\hline Conger cinereus & & 1 & & 2.8 & 0.3 & & & & \\
\hline \multicolumn{10}{|l|}{ Synodontidae } \\
\hline Synodus spp. & B & & 4 & 8.3 & 1.2 & & & & \\
\hline \multicolumn{10}{|l|}{ Aulostomidae } \\
\hline Aulostomus chinensis & & & 2 & 2.8 & 0.6 & & & & \\
\hline \multicolumn{10}{|l|}{ Fistulariidae } \\
\hline Fistularia commersonii & & & 6 & 8.3 & 1.8 & & & & \\
\hline \multicolumn{10}{|l|}{ Apogonidae } \\
\hline Foa brachygramma & B & & 5 & 5.6 & 1.5 & 2 & & 6.3 & 0.4 \\
\hline Pristiapogon kallopterus & B & & 1 & 2.8 & 0.3 & & 30 & 6.3 & 5.9 \\
\hline \multicolumn{10}{|l|}{ Carangidae } \\
\hline Caranx melampygus & & & 1 & 2.8 & 0.3 & & & & \\
\hline \multicolumn{10}{|l|}{ Lutjanidae } \\
\hline Aprion virescens & & & & & & & 1 & 6.3 & 0.2 \\
\hline \multicolumn{10}{|l|}{ Mulllidae } \\
\hline Mulloidichthys spp. & B & & & & & & 1 & 6.3 & 0.2 \\
\hline \multicolumn{10}{|l|}{ Scorpaenidae } \\
\hline Pterois sphex & E & & & & & 1 & & 6.3 & 0.2 \\
\hline Scorpaenopsis diabolus & B & & 1 & 2.8 & 0.3 & & & & \\
\hline \multicolumn{10}{|l|}{ Chaetodontidae } \\
\hline Chaetodon miliaris & E & & & & & & 1 & 6.3 & 0.2 \\
\hline Heniochus diphreutes & & & & & & & 1 & 6.3 & 0.2 \\
\hline \multicolumn{10}{|l|}{ Pomacanthidae } \\
\hline Centropyge fisheri & E & & 2 & 2.8 & 0.6 & & & & \\
\hline \multicolumn{10}{|l|}{ Pomacentridae } \\
\hline Dascyllus albisella & E & & & & & 2 & 50 & 12.5 & 10.2 \\
\hline \multicolumn{10}{|l|}{ Labridae } \\
\hline Cheilio inermis & & 1 & 7 & 5.6 & 2.4 & & 2 & 6.3 & 0.4 \\
\hline Cymolutes lecluse & E,B & 1 & 8 & 11.1 & 2.7 & & & & \\
\hline Cymolutes praetextatus & $\mathrm{B}$ & & 10 & 13.9 & 3.0 & & & & \\
\hline Iniistius baldwini & B & & & & & & 1 & 6.3 & 0.2 \\
\hline Iniistius umbrilatus & E,B & & & & & & 1 & 6.3 & 0.2 \\
\hline Novaculichthys taeniourus & B & & 7 & 5.6 & 2.1 & & & & \\
\hline Oxycheilinus bimaculatus & & 10 & 104 & 41.7 & 34.1 & 5 & & 12.5 & 1.0 \\
\hline Pseudojuloides cerasinus & & 2 & 24 & 16.7 & 7.8 & 1 & 13 & 12.5 & 2.7 \\
\hline Pseudocheilinus evanidus & & & & & & & 1 & 6.3 & 0.2 \\
\hline Pseudocheilinus tetrataenia & & & & & & & 1 & 6.3 & 0.2 \\
\hline Stethojulis balteata & E,B & & 9 & 13.9 & 1.2 & & & & \\
\hline \multicolumn{10}{|l|}{ Callionymidae } \\
\hline Callionymus decoratus & E,B & & 2 & 2.8 & 0.6 & & & & \\
\hline Synchiropus corallinus & $\mathrm{B}$ & & & & & 2 & & 6.3 & 0.4 \\
\hline Synchiropus rosulentus & E,B & & & & & 6 & & 6.3 & 1.2 \\
\hline Synchiropus spp. & B & & & & & 1 & 79 & 12.5 & 15.7 \\
\hline
\end{tabular}


9

10

11

Table 2 (continued)

\begin{tabular}{|c|c|c|c|c|c|c|c|c|c|}
\hline \multirow[b]{2}{*}{ Species } & \multirow[b]{2}{*}{$\mathrm{E}, \mathrm{B}$} & \multicolumn{4}{|c|}{ Meadow Canopy } & \multicolumn{4}{|c|}{$\underline{\text { Sand/Rubble }}$} \\
\hline & & $\mathrm{CO}(\mathrm{N})$ & $\mathrm{V}(\mathrm{N})$ & $\% \mathrm{Occ}$ & $\%$ RA & $\mathrm{CO}(\mathrm{N})$ & $\mathrm{V}(\mathrm{N})$ & $\%$ Occ & $\%$ RA \\
\hline \multicolumn{10}{|l|}{ Pinguipedidae } \\
\hline Parapercis schauinslandii & B & & 27 & 8.3 & 8.1 & 4 & 2 & 25.0 & 1.2 \\
\hline \multicolumn{10}{|l|}{ Gobiidae } \\
\hline Eviota susanae & E,B & & & & & 1 & & 6.3 & 0.2 \\
\hline Gnatholepis spp. & B & 21 & 1 & 33.3 & 6.6 & 13 & 1 & 37.5 & 2.7 \\
\hline Opua nephodes & B & 1 & 28 & 11.1 & 8.7 & 15 & 151 & 31.3 & 32.5 \\
\hline Priolepis eugenius & E,B & & & & & 1 & & 6.3 & 0.2 \\
\hline Priolepis farcimen & E,B & & & & & 1 & & 6.3 & 0.2 \\
\hline Psilogobius mainlandi & E,B & 2 & & 5.6 & 0.6 & 11 & 96 & 31.3 & 21.0 \\
\hline \multicolumn{10}{|l|}{ Microdesmidae } \\
\hline Gunnelichthys curiosus & B & & 4 & 8.3 & 1.2 & & 2 & 6.3 & 0.4 \\
\hline \multicolumn{10}{|l|}{ Acanthuridae } \\
\hline Acanthurus blochii & & & 3 & 2.8 & 0.9 & & & & \\
\hline \multicolumn{10}{|l|}{ Bothidae } \\
\hline Bothus pantherinus & B & & 4 & 11.1 & 1.2 & & 5 & 25.0 & 1.0 \\
\hline \multicolumn{10}{|l|}{ Balistidae } \\
\hline Rhinecanthus aculeatus & B & & 2 & 2.8 & 0.6 & & & & \\
\hline \multicolumn{10}{|l|}{ Monacanthidae } \\
\hline Aluterus scriptus & & & 1 & 2.8 & 0.3 & & & & \\
\hline \multicolumn{10}{|l|}{ Ostraciidae } \\
\hline Ostracion meleagris & & & 2 & 5.6 & 0.6 & & & & \\
\hline \multicolumn{10}{|l|}{ Tetraodontidae } \\
\hline Arothron hispidus & B & & 4 & 5.6 & 1.2 & & & & \\
\hline Canthigaster coronata & B & & 2 & 5.6 & 0.6 & & & & \\
\hline Canthigaster jactator & E,B & & 23 & 19.4 & 6.9 & & 3 & 6.3 & 0.6 \\
\hline \multicolumn{10}{|l|}{ Diodontidae } \\
\hline Diodon hystrix & $\mathrm{B}$ & & 1 & 2.8 & 0.3 & & & & \\
\hline
\end{tabular}

12 


\section{Table 3 (on next page)}

Checklist of fishes found in association with deep-water Avrainvillea sp. meadows based on clove-oil collections and visual surveys.

All abbreviations follow table 2 . 
1 Table 3. Checklist of fishes found in association with deep-water Avrainvillea sp. meadows based on clove-oil collections and

2 visual surveys. All abbreviations follow table 2.

\begin{tabular}{|c|c|c|c|c|c|c|c|c|c|}
\hline \multirow[b]{2}{*}{ Species } & \multirow[b]{2}{*}{$\mathrm{E}, \mathrm{B}$} & \multicolumn{4}{|c|}{ Meadow Canopy } & \multicolumn{4}{|c|}{ 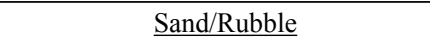 } \\
\hline & & $\mathrm{CO}(\mathrm{N})$ & $\mathrm{V}(\mathrm{N})$ & $\% \mathrm{Occ}$ & $\%$ RA & $\mathrm{CO}(\mathrm{N})$ & $\mathrm{V}(\mathrm{N})$ & $\% \mathrm{Occ}$ & $\%$ RA \\
\hline \multicolumn{10}{|l|}{ Muraenidae } \\
\hline Gymnothorax spp. & & 1 & 1 & 20.0 & 2.2 & & & & \\
\hline \multicolumn{10}{|l|}{ Serranidae } \\
\hline Plectranthias nanus & $\mathrm{B}$ & & & & & 1 & & 33.3 & 2.3 \\
\hline Pseudanthias bicolor & & & & & & 2 & & 66.7 & 4.7 \\
\hline \multicolumn{10}{|l|}{ Apogonidae } \\
\hline Apogonichthys perdix & & 9 & & 60.0 & 10.0 & 2 & & 33.3 & 4.7 \\
\hline \multicolumn{10}{|l|}{ Carangidae } \\
\hline Caranx lugubris & & & 1 & 10.0 & 1.1 & & & & \\
\hline \multicolumn{10}{|l|}{ Lutjanidae } \\
\hline Aprion virescens & & & 1 & 10.0 & 1.1 & & & & \\
\hline \multicolumn{10}{|l|}{ Mulllidae } \\
\hline Parupeneus multifasciatus & B & & & & & & 5 & 33.3 & 11.6 \\
\hline \multicolumn{10}{|l|}{ Scorpaenidae } \\
\hline Iracundus signifer & B & & & & & 2 & & 66.7 & 4.7 \\
\hline Sebastapistes fowleri & B & 1 & & 10.0 & 1.1 & 2 & & 66.7 & 4.7 \\
\hline \multicolumn{10}{|l|}{ Chaetodontidae } \\
\hline Chaetodon kleinii & & & & & & 1 & & 33.3 & 2.3 \\
\hline \multicolumn{10}{|l|}{ Pomacentridae } \\
\hline Chromis leucura & & & & & & 1 & & 33.3 & 2.3 \\
\hline \multicolumn{10}{|l|}{ Labridae } \\
\hline $\begin{array}{r}\text { Bodianus bilunulatus } \\
\text { albotaeniatus }\end{array}$ & E & & 1 & 10.0 & 1.1 & & & & \\
\hline Cirrhilabrus jordani & E & & 21 & 10.0 & 23.3 & & & & \\
\hline Oxycheilinus bimaculatus & & 4 & & 30.0 & 4.4 & 2 & 3 & 100.0 & 11.6 \\
\hline Pseudocheilinus evanidus & & 3 & & 30.0 & 3.3 & & 4 & 33.3 & 9.3 \\
\hline Pseudocheilinus octotaenia & & & & & & 1 & & 33.3 & 2.3 \\
\hline Pseudojuloides cerasinus & & 1 & 14 & 20.0 & 16.7 & & & & \\
\hline \multicolumn{10}{|l|}{ Callionymidae } \\
\hline Synchiropus corallinus & B & & & & & 1 & & 33.3 & 2.3 \\
\hline \multicolumn{10}{|l|}{ Pinguipedidae } \\
\hline Parapercis schauinslandii & B & & & & & 6 & & 66.7 & 14.0 \\
\hline \multicolumn{10}{|l|}{ Gobiidae } \\
\hline Gnatholepis spp. & B & & & & & & 2 & 33.3 & 4.7 \\
\hline \multicolumn{10}{|l|}{ Acanthuridae } \\
\hline Naso caesius & & & 30 & 10.0 & 33.3 & & & & \\
\hline \multicolumn{10}{|l|}{ Bothidae } \\
\hline Bothus pantherinus & B & & & & & & 1 & 33.3 & 2.3 \\
\hline \multicolumn{10}{|l|}{ Soleidae } \\
\hline Aseraggodes borehami & E,B & & & & & 1 & & 33.3 & 2.3 \\
\hline Balistidae & & & & & & & & & \\
\hline Xanthichthys auromarginatus & & & 1 & 10.0 & 1.1 & & & & \\
\hline Monacanthidae & & & & & & & & & \\
\hline Cantherhines dumerilii & B & & & & & & 2 & 33.3 & 4.7 \\
\hline Aluterus scriptus & & & & & & & 3 & 33.3 & 7.0 \\
\hline Tetraodontidae & & & & & & & & & \\
\hline Arothron hispidus & B & & 1 & 10.0 & 1.1 & & & & \\
\hline Canthigaster coronata & $\mathrm{B}$ & & & & & & 1 & 33.3 & 2.3 \\
\hline
\end{tabular}

3 


\section{Table 4 (on next page)}

Abundance and density of fishes from 1.5 m clove oil collections within Halimeda kanaloana canopy $(n=28)$ and surrounding sand $\&$ rubble $(n=12)$ sub-habitats.

Median abundance (fish per $1.5 \mathrm{~m}$ collection, N), species richness (S), and a Shannon-Wiener diversity index $\left(\mathrm{H}^{\prime}\right)$ are included at bottom. All other abbreviations follow table 2 . Note that the abundance of vagile species $(*)$ may be underestimated as these species tend to swim away when the tarp is being deployed. 
1 Table 4. Abundance and density of fishes from $1.5 \mathrm{~m}$ clove oil collections within Halimeda kanaloana canopy ( $\mathrm{n}=28)$ and surrounding sand \& rubble $(\mathrm{n}=12)$ sub-habitats. Median abundance (fish per $1.5 \mathrm{~m}$ collection, $\mathrm{N}$ ), species richness (S), and a Shannon-Wiener diversity index $\left(\mathrm{H}^{\prime}\right)$ are included at bottom. All other abbreviations follow table 2. Note that the abundance of vagile species $(*)$ may be underestimated as these species tend to swim away when the tarp is being deployed.

\begin{tabular}{|c|c|c|c|c|c|}
\hline Species & E,B & $\begin{array}{c}\text { Meadow } \\
(\mathrm{N})\end{array}$ & $\begin{array}{l}\text { Meadow Density } \\
\text { (fish per } \mathrm{m}^{2} \text { ) }\end{array}$ & $\begin{array}{l}\text { Sand } \\
(\mathrm{N})\end{array}$ & 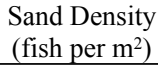 \\
\hline \multicolumn{6}{|l|}{ Congridae } \\
\hline Conger cinereus* & & 1 & 0.0238 & 0 & 0 \\
\hline \multicolumn{6}{|l|}{ Apogonidae } \\
\hline Foa brachygramma* & B & 0 & 0 & 2 & 0.1111 \\
\hline \multicolumn{6}{|l|}{ Scorpaenidae } \\
\hline Unidentified $^{*}$ & & 1 & 0.0238 & 0 & 0 \\
\hline Pterois sphex* & $\mathrm{E}$ & 0 & 0 & 1 & 0.0556 \\
\hline \multicolumn{6}{|l|}{ Pomacentridae } \\
\hline Dascyllus albisella* & $\mathrm{E}$ & 0 & 0 & 2 & 0.1111 \\
\hline \multicolumn{6}{|l|}{ Labridae } \\
\hline Cheilio inermis* & & 1 & 0.0238 & 0 & 0 \\
\hline Cymolutes lecluse* & E,B & 1 & 0.0238 & 0 & 0 \\
\hline Oxycheilinus & & 10 & 0.2381 & 5 & 0.2778 \\
\hline \multicolumn{6}{|l|}{ bimaculatus* } \\
\hline Pseudojuloides cerasinus* & & 2 & 0.0476 & 1 & 0.0556 \\
\hline \multicolumn{6}{|l|}{ Callionymidae } \\
\hline Synchiropus corallinus & $\mathrm{B}$ & 0 & 0 & 2 & 0.1111 \\
\hline Synchiropus rosulentus & E,B & 0 & 0 & 7 & 0.3889 \\
\hline \multicolumn{6}{|l|}{ Pinguipedidae } \\
\hline $\begin{array}{c}\text { Parapercis } \\
\text { schauinslandii* }\end{array}$ & B & 0 & 0 & 4 & 0.2222 \\
\hline \multicolumn{6}{|l|}{$\begin{array}{l}\text { schaulnslandll* } \\
\text { Gobiidae }\end{array}$} \\
\hline Eviota susanae & $\mathrm{B}, \mathrm{E}$ & 0 & 0 & 1 & 0.0556 \\
\hline Gnatholepis anjerensis & $\mathrm{B}$ & 20 & 0.4762 & 12 & 0.6667 \\
\hline Gnatholepis cauerensis & E,B & 1 & 0.0238 & 1 & 0.0556 \\
\hline Opua nephodes & E,B & 1 & 0.0238 & 15 & 0.8333 \\
\hline Priolepis eugenius & E,B & 0 & 0 & 1 & 0.0556 \\
\hline Priolepis farcimen & E,B & 0 & 0 & 1 & 0.0556 \\
\hline Psilogobius mainlandi & E,B & 1 & 0.0238 & 11 & 0.6111 \\
\hline Median Abundance $\left(\mathrm{N}_{\mathrm{x}}\right)$ & & 1 & & 4 & \\
\hline Median Species Richness $\left(S_{x}\right)$ & & 1 & & 1 & \\
\hline Total Species Richness (S) & & 10 & & 15 & \\
\hline Diversity $\left(\mathrm{H}^{\prime}\right)$ & & 1.5013 & & 2.2474 & \\
\hline Average Species Density $\mathrm{m}^{2}$ & & & 0.0489 & & 0.1930 \\
\hline Median Density of Fishes $\mathrm{m}^{2}$ & & & 0.6667 & & 2.6667 \\
\hline Average Density of Fishes $\mathrm{m}^{2}$ & & & 0.9286 & & 3.6667 \\
\hline
\end{tabular}




\section{Table 5 (on next page)}

Abundance and density of fishes from $1.5 \mathrm{~m}$ clove oil collections within Avrainvillea sp. canopy $(n=8)$ and surrounding sand \& rubble $(n=3)$ sub-habitats.

Median abundance (fish per 1.5 m collection, $N$ ), species richness (S), and a Shannon-Wiener diversity index $\left(\mathrm{H}^{\prime}\right)$ are included at bottom. All other abbreviations follow table 2 . Note that the abundance of vagile species $(*)$ may be underestimated as these species tend to swim away when the tarp is being deployed. 
1 Table 5. Abundance and density of fishes from $1.5 \mathrm{~m}$ clove oil collections within Avrainvillea sp. canopy ( $\mathrm{n}=8)$ and surrounding sand \& rubble $(\mathrm{n}=3)$ sub-habitats. Median abundance (fish per $1.5 \mathrm{~m}$ collection, $\mathrm{N})$, species richness $(\mathrm{S})$, and a Shannon-Wiener diversity index (H') are included at bottom. All other abbreviations follow table 2. Note that the abundance of vagile species $(*)$ may be underestimated as these species tend to swim away when the tarp is being deployed.

\begin{tabular}{|c|c|c|c|c|c|}
\hline Species & $\mathrm{E}, \mathrm{B}$ & $\begin{array}{c}\text { Meadow } \\
(\mathrm{N})\end{array}$ & $\begin{array}{c}\text { Meadow Density } \\
\left(\text { fish per } \mathrm{m}^{2}\right)\end{array}$ & $\begin{array}{l}\text { Sand } \\
(\mathrm{N})\end{array}$ & $\begin{array}{l}\text { Sand Density } \\
\left(\text { fish per } \mathrm{m}^{2} \text { ) }\right.\end{array}$ \\
\hline \multicolumn{6}{|l|}{ Muraenidae } \\
\hline Gymnothorax spp. & & 1 & 0.0833 & 0 & 0 \\
\hline \multicolumn{6}{|l|}{ Serranidae } \\
\hline Plectranthias nanus & $\mathrm{B}$ & 0 & 0 & 1 & 0.2222 \\
\hline Pseudanthias bicolor & & 0 & 0 & 2 & 0.4444 \\
\hline \multicolumn{6}{|l|}{ Apogonidae } \\
\hline Apogonichthys perdix & & 9 & 0.7500 & 2 & 0.4444 \\
\hline \multicolumn{6}{|l|}{ Scorpaenidae } \\
\hline Iracundus signifer & $\mathrm{B}$ & 0 & 0 & 2 & 0.4444 \\
\hline Scorpaenopsis fowleri & $\mathrm{B}$ & 1 & 0.0833 & 2 & 0.4444 \\
\hline Unident & & 0 & 0 & 1 & 0.2222 \\
\hline \multicolumn{6}{|l|}{ Chaetodontidae } \\
\hline Chaetodon kleinii & & 0 & 0 & 1 & 0.2222 \\
\hline \multicolumn{6}{|l|}{ Pomacentridae } \\
\hline Chromis leucura & & 0 & 0 & 1 & 0.2222 \\
\hline \multicolumn{6}{|l|}{ Labridae } \\
\hline Oxycheilinus bimaculatus & & 4 & 0.3333 & 2 & 0.4444 \\
\hline Pseudocheilinus evanidus & & 3 & 0.2500 & 0 & 0 \\
\hline Pseudocheilinus octotaenia & & 0 & 0 & 1 & 0.2222 \\
\hline Pseudojuloides cerasinus & & 1 & 0.0833 & 0 & 0 \\
\hline \multicolumn{6}{|l|}{ Callionymidae } \\
\hline Synchiropus corallinus & B & 0 & 0 & 1 & 0.2222 \\
\hline \multicolumn{6}{|l|}{ Pinguipedidae } \\
\hline Parapercis schauinslandii & B & 0 & 0 & 6 & 1.3333 \\
\hline \multicolumn{6}{|l|}{ Soleidae } \\
\hline Aseraggodes borehami & $\mathrm{E}, \mathrm{B}$ & 0 & 0 & 1 & 0.2222 \\
\hline Median Abundance $\left(\mathrm{N}_{\mathrm{x}}\right)$ & & 2.50 & & 7.00 & \\
\hline Median Species Richness $\left(\mathrm{S}_{\mathrm{x}}\right)$ & & 2 & & 6 & \\
\hline Total Species Richness (S) & & 6 & & 13 & \\
\hline Diversity $\left(\mathrm{H}^{\prime}\right)$ & & 1.4383 & & 2.3667 & \\
\hline Average Species Density m² & & & 0.0990 & & 0.3194 \\
\hline Median Density of Fishes $\mathrm{m}^{2}$ & & & 1.6667 & & 4.6667 \\
\hline Average Density of Fishes $\mathrm{m}^{2}$ & & & 1.5833 & & 5.1111 \\
\hline
\end{tabular}

5 